\title{
OPTIMUM RESOURCE ALLOCATION AND ELIMINATING WASTE INSIDE THE FOOD INDUSTRY
}

\author{
Sathiyabama, C. N., Dasan, P.
}

This article seeks to allocate optimum resources for the wrapping section and suggesting a suitable method that needs to be in place for successful elimination of waste inside the food industry's wrapping section. It also includes identifying the main reasons for various types of wastages inside the wrapping section and cost of all the wastages. The paper is based on observation and research using the approach of lean tools and techniques. The methodology used for evaluating data is value stream mapping and some statistical SPSS tools for analysis. Data are real and are gathered from three different production shifts inside a food industry wrapping section. The main reasons for wastages inside the wrapping section are highlighted. Finally, the paper was concluded by estimating total cost of wastages and recommending a suitable way to save wastage costs. The need to change the jaws inside the wrapping machines, regular maintenance of all machines throughout the industry and training of personnel are recommended. The possible methods along with their benefits to reduce waste, operators, improve productivity and business growth were also highlighted.

JEL Classification: C40, C44, C41, C81

Keywords: LEAN Methodology, Optimization in Food Logistics, Operations in Food Industry

\section{Introduction}

In the current modern life style, wrapping of food products is considered to be an essential component because it embraces all stages of activities involved in transporting goods and services from producers to the customers. Wrapping is an important part of an organization's branding process because it plays a very important role in communicating the image and identity of a company and the products.

If the products and wrapping create some quality issues and wastages then there are many consequences an organization might need to face. Each and every activity inside the wrapping section impacts directly on cost because the wastages of resources and products cause an unnecessary expense to the company. It results in reduction of productivity, increases lead time, and reworks and affects the dispatching schedule of the products. As a result, this affects the time, cost and quality and customer satisfaction so waste should be eliminated. Therefore, this research work is mainly focused on lean manufacturing of applying lean tools and techniques to reduce waste and allocate optimum resources for a food industry wrapping section.

This research is carried out in a food industry situated in the United Kingdom. The company produces a wide range of bread based products as well as some other special products like Sushi.

\subsection{Current Process}

The process inside the wrapping section is divided into five stages as follows:

1. Product splitting,

2. Allocating in room conveyor,

3. Barcode labeling and wrapping,

4. Metal detector and

5. Loading products into the basket for dispatch.

Initially, the products from production come in batches of around 35, so at the starting point of the wrapping section in line 1 , there is a need of operators to break the product into 6 or 4 depending upon the requirements. In contrast, at the starting point of line 2 and 3 , the operators divide the products and direct them to line 2 and 3 separately. Next, the products are grouped into 4 or 6 by the operators and allocated into the room conveyor for wrapping. In all these above stages, the products are checked for quality and if any product lacks quality like poor toppings, over baked, over topped, variation in size and shape, they are considered to be waste. Both the activities like barcode labeling and wrapping and metal detecting are done by the machines and one operator is in charge of operating machine settings and recording periodic readings for once every half an hour. Once the product is wrapped, it passes through the metal detector. The metal detector checks for any quality issues and metals present inside 
Figure 1: Current state of the wrapping section

\begin{tabular}{|c|c|c|c|c|c|c|c|}
\hline \multicolumn{8}{|c|}{ CURRENT STATE } \\
\hline Process Attributes & $\begin{array}{l}\text { Product } \\
\text { Splitting }\end{array}$ & $\begin{array}{l}\text { Allocating } \\
\text { in room } \\
\text { conveyor }\end{array}$ & $\begin{array}{l}\text { Barcode } \\
\text { labelling \& } \\
\text { wrapping }\end{array}$ & $\begin{array}{c}\text { Metal } \\
\text { detector }\end{array}$ & $\begin{array}{l}\text { Loading products } \\
\text { into the basket for } \\
\text { despatch }\end{array}$ & Total & $\begin{array}{l}\text { Total lead } \\
\text { time }\end{array}$ \\
\hline \multicolumn{8}{|l|}{ LINE 1} \\
\hline Operators & 2 & 6 & 1 & 0 & 1 & 10 & $640 \mathrm{sec}$ \\
\hline Cycle Time (in sec) & 1.4 & 1.5 & 0.6 & 1 & 1.8 & 6.3 & \\
\hline Change over (in sec) & 180 & 150 & 30 & 120 & 90 & & \\
\hline Breakdown (in sec) & 0 & 0 & 3600 & 0 & 0 & & \\
\hline Available Time (in sec) & 82800 & 82800 & 82800 & 82800 & 82800 & & \\
\hline Uptime & $99.70 \%$ & $99.80 \%$ & $95.60 \%$ & $99.80 \%$ & $99.80 \%$ & & \\
\hline \multicolumn{8}{|l|}{ LINE 2 \& 3} \\
\hline Operators & 2 & 2 & 1 & 0 & 1 & 12 & $643.3 \mathrm{sec}$ \\
\hline Cycle Time (in sec) & 1.8 & 1.5 & 0.9 & 1.7 & 1.9 & 7.8 & \\
\hline Change over (in sec) & 120 & 150 & 45 & 140 & 120 & & \\
\hline Breakdown (in sec) & 0 & 0 & 3600 & 0 & 0 & & \\
\hline Available Time (in sec) & 82800 & 82800 & 82800 & 82800 & 82800 & & \\
\hline Uptime & $99.90 \%$ & $99.90 \%$ & $95.50 \%$ & $99.80 \%$ & $99.80 \%$ & & \\
\hline
\end{tabular}

the product and removes the product if they have any quality issues. Once all the above process is complete, the products are packed into the baskets by an employee for dispatch.

The wrapping section produces a large amount of waste. This causes unnecessary expense and requires additional operator costs which adds to the company's expenses.

- Presently 22 operators are working inside the wrapping section,

- Wrapping section Line 1 consists of 10 operators and

- 6 operators in each Line 2 and Line 3.

\subsection{Challenges in current state}

There is a need to reduce operators, materials and wastages inside the wrapping section.

1) To find out the total quantities of waste from the three wrapping lines.

2) To find the main reasons for waste inside the wrapping section.

3) To find how the current materials and information flow inside the wrapping section.

4) To find the total cost of waste inside the wrapping section.

5) What process change can be done to allocate optimal resources, reduce waste and improve productivity inside the wrapping section?

\subsection{System Study}

\subsubsection{Current Problems}

1. The main reason for product waste is due to the production activities.

2. Some parts of the bakery machines are defective.

3. There is no regular maintenance for machines.

4. The process inside the wrapping section also promotes unnecessary waste.

5. For certain processes, changeovers take longer.

6. The total lead time is very high.

7. Some employees inside the wrapping section are kept waiting.

8. The operator's efficiency is greatly reduced due to this activity.

9. The work area is not as clean as it could be.

10. The jaws that are present inside the wrapping machines in line 1, 2 and 3 cause unnecessary waste during wrapping.

\section{Literature Review}

\subsection{Lean manufacturing}

The principles of lean manufacturing have become more important in the current world for designing manufacturing and implementation. It has been considered to be a major requirement in the current competitive world (Matt, 2008). The phrase „lean concept” was primarily 
Figure 2: Model of Two dimensional Supply Chain Performance

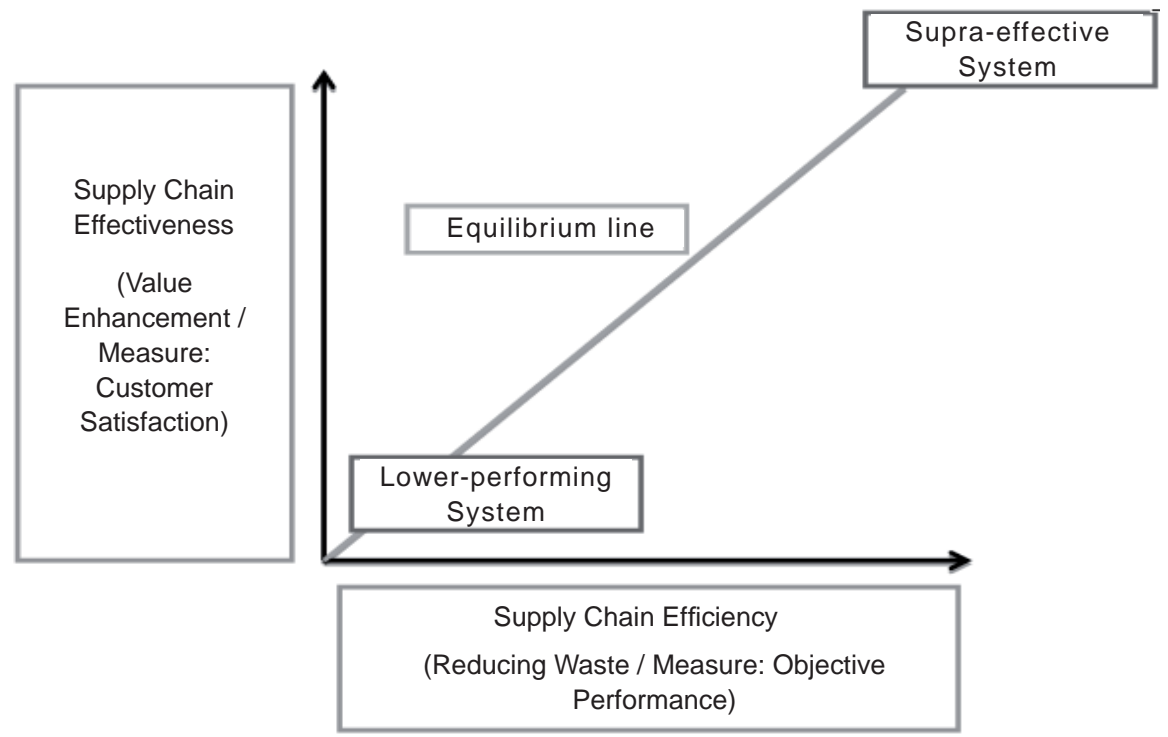

Source: Hines, Holweg and Rich (2004)

presented by Womack, Jones and Roos (2007) in "The Machines that Changed the World". Additionally, the authors projected some group of principles to achieve a lean endeavor. It involves understanding of the tools like value stream mapping, work flow improvement, pull systems and continuous perfection. However, during the transformations of lean manufacturing, many conversions fail to focus on customer value and become focused on delivering the approaches of quality-cost improvements (Hines, Holweg and Rich, 2004). The lean language states that any activities that are disconnected from customer value are considered to be waste or non-value adding (Monden, 1993). Lean manufacturing is entrenched in TPS, which mainly aims to eliminate non-value adding activities like waste. According to Ohno (1988), waste is an individual activity, which makes use of resources with no value added. The vision creates an insight of reducing waste inside the organization and entire value chain. As prescribed by Womack and Jones (1996), the practice of lean thinking and its principles have been productively implemented to many operations and manufacturing environments (Eatock, Dixon and Young, 2009, Papadopoulou and Özbayrak, 2005, Taj, 2008, Haque and James-Moore, 2004, Chowdary and George, 2012). The vital component of a lean pattern is to control processes through administration by measuring key performances (Imaj, 1997, Taylor, 2006, Zokaei and Simons, 2006).

The concept of 'lean' is more conspicuous in global management to improve the performance within the company and between the companies. There may be some misunderstanding about the significance of performance and its elements. According to Mentzer and Konrad (1991), measuring performance is examining effectiveness and efficiency for a particular task. Similarly, Kao et al. (1995), Young, Shields and Wolf (1988) and Frøkjær, Hertzum and Hornbæk (2000) argue the same concept of effectiveness and efficiency move towards the inter organization operational performance but Mentzer and Konrad (1991) define efficiency as the proportion of utilized resources against derived results and defines effectiveness as the point to which our target is achieved. On the other hand, Young, Shields and Wolf (1988) put forward an altered explanation for performance efficiency: „producing the actual quantity required with minimum resources and waste". He also argues that effectiveness is the ability of producing an anticipated result.

In order to avoid the above confusion, Nielsen and Levy (1994) argued that performance in supply chain is a two dimensional definition which involves effectiveness and efficiency as shown in the (Figure 1).

From the above diagram, performing things ,right" is called efficiency and performing the ,right things" is called effectiveness. Effectiveness speaks about customer satisfaction; on the other hand, efficiency narrates the objective performance. It is the measuring of amount produced against the contributed level (Zokaei and Simons, 2006). So, in this food industry, effectiveness indicates its customer satisfaction and the 
Figure 3: Lean effectiveness vs. efficiency

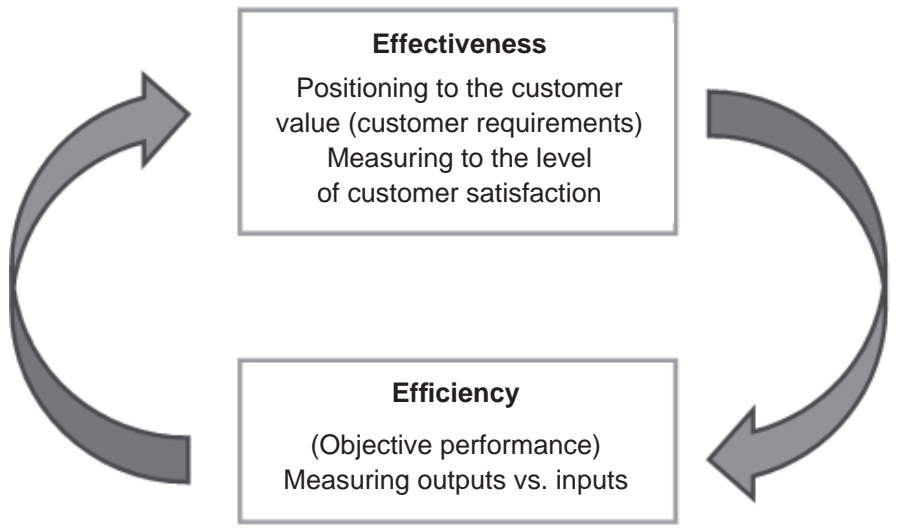

Source: Evans and Simons (2000)

daily process efficiency within the wrapping section can be measured by calculation of actual work done against targeted work on that particular day. Productivity can be measured by trays produced against labor time. In another example, for instance, effectiveness can also be improved by adding new features to the product to fulfill unmet customer need or the current process can be slightly modified to deliver the actual requirement of the final customer. On the other hand, efficiency levels can be increased by eliminating waste by decreasing the input levels while raising the output levels. So, in this food industry, reducing waste inside the three wrapping lines can improve efficiency. Figure 2 argues that supply chain efficiency is conditional to the entire effectiveness of the value plan (Zokaei and Simons, 2006).

From the above (Figure 2), effectiveness improvement and efficiency improvement by reducing waste can directly impact on cost savings. Until now, the literature focused on overlooking the improvement of effectiveness and efficiency. If we consider the following three articles by noticeable lean thinkers highlighting the significance of „understanding the customer value“ by Hines, Holweg and Rich (2004), „lean consumption“ by Womack and Jones (1996) and „Identifying the determinants of value in UK red meat industry" by Simons et al. (2003), these articles take us to the debate of customer requirements through the concept of effectiveness in supply chain and links customer value at every stage of the supply chain.

In general, for measuring and improving effectiveness, there is a need of quality tools and techniques. Among the literature, there are various lean tools and techniques available. Value stream mapping and cellular manufacturing are the most popular tools that are generally accepted by manufacturing areas. Within various levels of manufacturing set-up, value stream mapping is used for basic level analysis of information and material flow (Serrano, Ochoa and Castro, 2008, Vinodh, Arvind and Somanaathan, 2010). Some studies have examined some issues involved in designing cellular systems (Hunter and Black, 2007, Slomp, Chowdary and Suresh, 2005) normally, while considering the process of designing the cell, it is done by selecting and grouping the machines into cells (Angra, Sehgal and Samsudeen Noori, 2008, Chowdary and George, 2012).

According to Albert (2004), setup reduction provides benefits to the lean manufacturing environment. Yang and Su (2007) proposed a concept of lean operation for production improvement in a semi-conductor industry. Achanga et al. (2006) has identified a number of crucial factors that regulate the victory of implementing lean within the small manufacturing enterprise. Papadopoulou and Özbayrak (2005) have stressed the misunderstanding about surrounding issues in lean and also identified the important concepts and ways that include leanness. Taj (2008) examined the variation of lean principles and evaluated its current practice in various organizations in China including pharmaceutical, chemical and food industries. Barla (2003) used mathematical modeling to select suppliers for lean supply. The manufacturing waste and faults must be reduced to improve process efficiency and production time in any manufacturing industry. Vinodh, Arvind and Somanaathan (2010) and Khamis et al. (2009) discovered the realistic use of 5S for health and safety and housekeeping between two industrial organizations. A research study was carried out by Yusuf and Adeleye (2002) on "lean and agile manufacturing related to current practices in UK”. 


\subsubsection{Benefits of Lean}

From all the above literature, the benefits of lean are: reduces floor space, inventories, improves employee engagement and satisfaction, and improves lead time and quality. It highly reduces the cost because of reducing non-value added activities and minimizes double handling and reworks. Lean enables cultural change in a company which tends to encourage employees to constantly think about process improvement. As a result, it enhances the profitable growth (Khatri, 2009).

\subsubsection{Limitations of Lean}

According to Tapping, Luyster and Shuker (2002), in the case it is too difficult to consume customer requirements, if there are too many distinctive requirements, or if the orders are not the same and if there are more product variations in the production line, then these might be a common excuse for not implementing lean. Some of the limitations of lean include the fact that sometimes the problem solving tools are simple, which may not be suitable for prolonged problems. Instilling the lean concept into the working culture can take quite a lot of years and requires constant support and assistance from the management (Khatri, 2009). Though lean has some simple problem solving tools, it also has some powerful tools like value stream mapping, etc. By using this tool, we can solve prolonged problems in any food industry. Also, with the help of constant support from top management, any limitations can be overcome.

\subsection{Lean tools and Applications}

\subsubsection{Research on Value Stream Mapping}

This segment explains about the strength of value stream mapping and also provides an idea about where this lean tool has been used in manufacturing sectors. Even though lean provides effectiveness, productivity improvement, customer satisfaction, product quality, some production industries are not completely developing the entire strength of lean concepts and techniques related with lean philosophy (Chen, Li and Shady, 2010). Currently, value stream mapping has become the most accepted method for implementing lean manufacturing (Vinodh, Arvind and Somanaathan, 2010, Lian and Van Landeghem, 2007). Hence this segment presents the necessary factors to develop the complete strength of lean tools.

The process of planning and collaborating on a lean program through an efficient data capture and analysis is called value stream management (Tapping, Luyster and Shuker, 2002). According to Tapping, Luyster and Shuker (2002), there are eight steps to be followed in this management process. Initially every organization should commit and dedicate to lean. Secondly, preferences for a value stream should be high. Followed by the above two steps, an organization should gain knowledge about lean tools and techniques. Once all the above process is completed, the current process flow should be mapped. The lean metrics should be determined and future state map should be mapped. After all the above process is completed, kaizen plans should be created and implemented.

The value stream management has its own different approach. By applying lean tools and techniques, the organization's behaviors can be structured and the attitudes of employees may start to change. Value stream mapping is an effective tool that identifies all the activities occurring along a value stream for a product or family. It is used to map the entire material and information flow for the current state and based on that analysis, the future state is designed for process improvement (Tapping, Luyster and Shuker, 2002).

Michael Porter (1985) of Harvard Business School introduced the system to analyze the value chain for competitive advantage. Value chain analysis is structured in a way to analyze all the activities related to cost and/or segregation of the value chain. Through value chain, the cost can be minimized or segregation can be enhanced (Dekker, 2003, Zokaei and Simons, 2006). Food value chain analysis is developed by Food Process Innovation Unit at Cardiff Business School. It provides a systematic map of the value chain and analysis of each strategic activity systematically related to the customer's value. Based on this, both the value stream mapping and value chain analysis extensively draws upon lean standards (Rother and Shook, 1999, Jones and Womack, 2000, Hines and Rich, 1997). The food value chain analysis method has been widely adapted by numerous agri-food sectors in the UK that include food products like meat, dairy, cereals, etc. This methodology also includes value stream mapping tools that determine and analyze the time and quality. The following section explains about the application of value stream mapping.

McDonald, Van Aken and Rentes (2002) has offered a concept of value stream mapping along with simulation to a production line to improve productivity in a manufacturing company. Also Seth and Gupta (2005) have explained about the use of value stream mapping in an auto industry setting to achieve improvement in productivity. Lummus, Vokurka and Rodeghiero (2006) has explained the ways to improve quality through value stream mapping tools by lowering the patient waiting time and improving the patient throughput in a small 
medical clinic. Lasa, Castro, and Laburu (2009) has proven that value stream mapping is the most suitable tool to redesign the production system. To identify the root cause of the problem, the „5 whys" method is widely used. This helps the company to progress in the future state (Chowdary and George, 2012). Waste removal may help in enhancing the efficiency of value chain and flow systems developments (Taylor, 2006). There are more tools to improve the value chain efficiency process stretching from system dynamics to improving operations and management of demand (Forrester, 1958, Towill, 1996, Bichino, 2000). The reduction of waste leads to improvement of ,flow systems ' both within the industry and between the industries; it also leads to reduction of cost every year and allows improvement in progress through cost, quality and service (Taylor, 2006). So the reduction of waste in Gunstones wrapping section may lead to the reduction of cost and may add value through improving quality and service and reducing cost.

Apart from the seven categories of waste like over production, unnecessary movements, transportation, inventory, reworks, over processing and unnecessary waiting, Figure 4 shows a different level of waste experienced in any production industry.

Hence, based on the above literature, value stream mapping is a simple tool that helps to identify non-value elements' time like waiting time, material handling time and time for rework. It also helps everyone, especially the operation managers, to understand how their current organizational flow operates and helps to analyze the existing flows and provide a design to improve the operation in the future. Based on the above (Figure 3), when we compare these with the operations in the food industry, many of the same wastes as above are experienced. So, if we reduce this waste, the service can be improved, the output results would be effective and the costs will be reduced. As a result, the above mentioned benefits can be achieved.

\subsubsection{Benefits of Value stream Mapping}

Based on the above literature, through value stream, the process of different parts of the business can be marked and it may be easy to understand the flow. By mapping the process into the value stream, the problems or bottle necks are revealed. It is very important to look at the value stream as a story board because, having visual representation of the process discovers the absolutely necessary parts that are more flexible and movable. It acts as a visual communication for everyone involved. It helps to reveal the waste in the business process. Based on the identified waste, decisions can be made to improve the process. Hence, it is a powerful tool for analysis and planning the current state and future state of the business process (Cequea, 2012).

\subsubsection{Limitations of Value Stream Mapping}

According to Hkrita (2009), the following are the limitations of value stream mapping: there may be a situation

Figure 4: Three different levels of waste

\begin{tabular}{|c|c|c|c|c|c|}
\hline \multicolumn{6}{|c|}{ LEVELS OF WASTE } \\
\hline & Level One & & Level Two & & Level Three \\
\hline $\begin{array}{l}\bullet \\
\square \\
\square \\
\square \\
\square \\
\square \\
\square \\
\square \\
\square \\
\square \\
\square\end{array}$ & $\begin{array}{l}\text { Work-in-progress } \\
\text { Very poor plant } \\
\text { design } \\
\text { Throw-outs } \\
\text { Returns } \\
\text { Rework } \\
\text { Damaged } \\
\text { product } \\
\text { Dirty Equipment } \\
\text { Container Size } \\
\text { Batch Size } \\
\text { Poorlighting } \\
\text { Material not } \\
\text { delivered to point } \\
\text { of use }\end{array}$ & $\begin{array}{l}\bullet \\
\square \\
\square \\
\square \\
\square \\
\square\end{array}$ & $\begin{array}{l}\text { ong Changeover } \\
\text { Poor workplace design } \\
\text { No regular maintenance } \\
\text { Temporary storage } \\
\text { Problems with Equipment } \\
\text { Unsafe methods }\end{array}$ & $\begin{array}{l}\bullet \\
\square \\
\square \\
\square \\
\square \\
\square \\
\square\end{array}$ & $\begin{array}{l}\text { Bending and Reaching } \\
\text { Double handling } \\
\text { Excess walking } \\
\text { Lookfor stock } \\
\text { Paperwork } \\
\text { Speed and feed } \\
\text { No Standard } \\
\text { Operating Procedures }\end{array}$ \\
\hline
\end{tabular}

Source: Tapping, Luyster and Shuker (2002) 
Figure 5: Total kilogram of waste from three wrapping lines

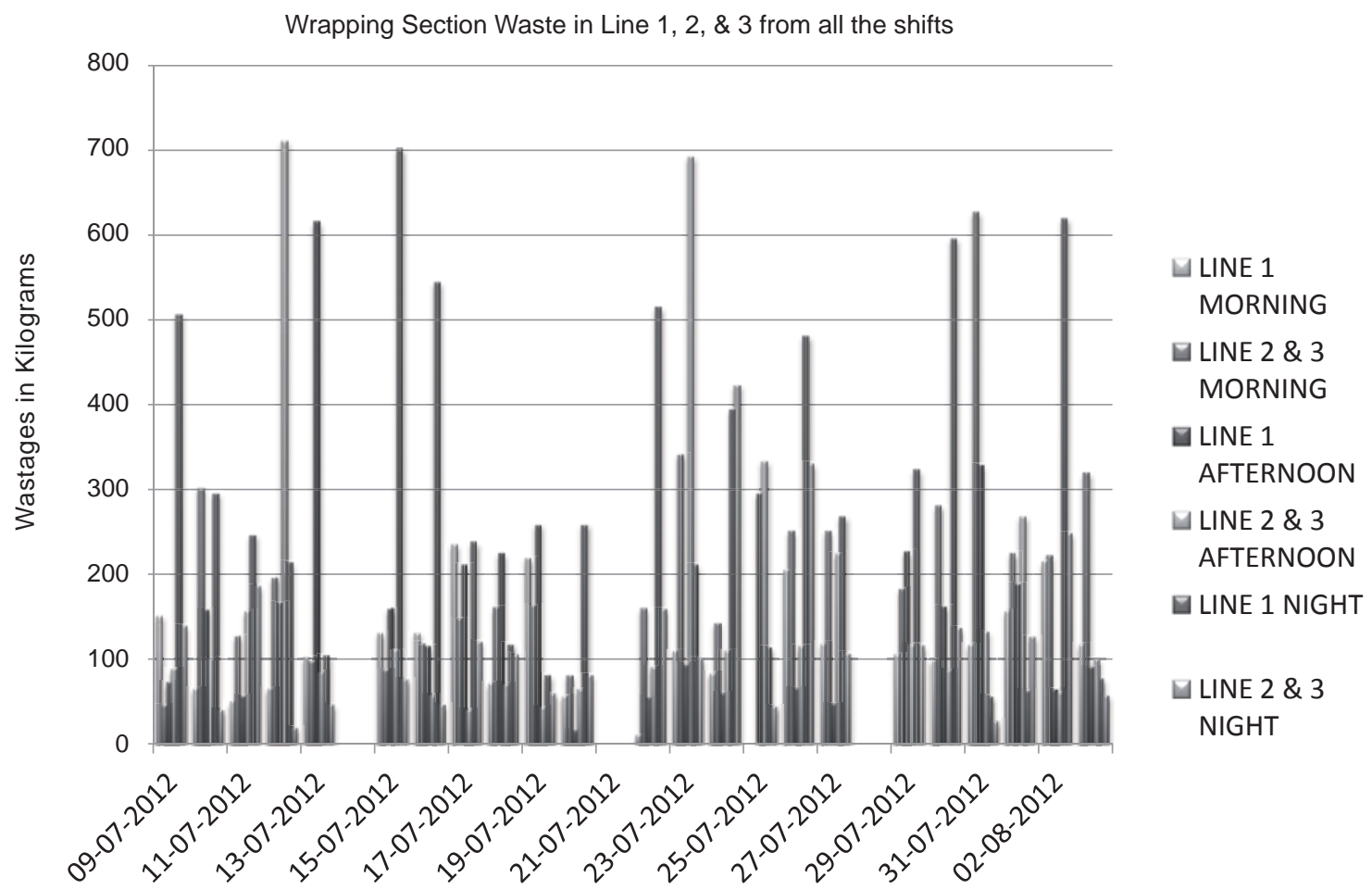

of attention deviation from significant characteristics of complex problems and unrealistic expectations. This may lead to the problem of over-hype. Any quality issues within the company can be addressed through six sigma and total quality management. $5 \mathrm{~S}$ helps to maintain the plant, improves safety and increase productivity. But value stream mapping alone addresses none of these. It may also consider the non-technical aspects of lean. Though value stream mapping has above limitations, it acts as a very good tool for products with a narrow family and for few customers. Value stream mapping works well for these situations. So, if we consider this food industry, though there are varieties of products, they all fall under narrow family. Hence, it can be applied to achieve all the above advantages.

Therefore from all the above literature, it is clear that to improve the product effectiveness and quality assurance, we have to eliminate waste, create value and improve the flow. Also as discussed earlier, value stream mapping helps in coordinating and analyzing the material and information flow. By doing so, quality can be built into the products throughout the production, as a result it reduces cycle time, reduce cost, reduce the buffer stocks and improve productivity. The following lean tools like value stream mapping, 5S, etc. can be applied to achieve our target.

\section{Design/Methodologylapproach}

1) The project is carried out inside food industry using the approach of lean tools and techniques.

2) The methodology used for evaluating data is value stream mapping and some statistical SPSS tools for analysis. Data are real and are gathered from three different production shifts inside food industry wrapping section.

\section{Findings}

This food industry produces many products. So, to choose a particular product for this research, product quality analysis and product routing analysis are carried out. Based on the above analysis, the products , $\mathrm{A}^{\text {' f from }}$ line 1 and , $\mathrm{B}^{\text {‘ }}$ from lines 2 and 3 are selected for this research.

\subsection{Total kilograms of waste from three wrapping lines}

During the time period of 25days in wrapping section,

1) Line 1 produced total of 13,302 kilograms of waste and

2) Lines 2 and 3 produced 11,111 kilograms of waste. 
Table 1: Overall calculation for various lines of the data collected from 9 July 2012 to 3 August 2012

\begin{tabular}{|c|c|c|}
\hline Production Line & Line 1 & Line $2 \& 3$ \\
\hline Product & Luxury Hot Cross & Soft White Seeded Rolls \\
\hline Number of buns & 48,000 & 40,000 \\
\hline Total Direct costs & $£ 5,744.85$ & $£ 2,948.59$ \\
\hline Cost of Ingredients & $£ 4,059.24$ & $£ 1,577.30$ \\
\hline Packaging Materials & $£ 405.18$ & $£ 176.36$ \\
\hline Direct Labour Cost & $£ 1,280.43$ & $£ 1,194.93$ \\
\hline Total Cost & $£ 11,489.70$ & $£ 5,897.18$ \\
\hline $\begin{array}{r}\text { Other Charges (Incidental and Overhead) } \\
10 \% \text { of Total Cost }\end{array}$ & $£ 1,148.97$ & $£ 589.72$ \\
\hline Gross Total & $£ 12,638.67$ & $£ 6,486.90$ \\
\hline Unit Cost of Bun & $£ 0.26$ & $£ 0.16$ \\
\hline Total Wastage (in Kg) & $13,301.55$ & $11,111.05$ \\
\hline Declared Weight of 4 Luxury hot cross buns in $\mathrm{Kg}$ & 0.31 & 0.27 \\
\hline Total Buns Wastages for 1 month & 42,908 & 41,152 \\
\hline Total Cost of Wastages from for 1 month & $£ 11,156$ & f 6584.33 \\
\hline Yearly Cost of Wastage & $£ 133,872$ & $f 79,011.96$ \\
\hline
\end{tabular}

Figure 6: Reason for waste inside the food industry

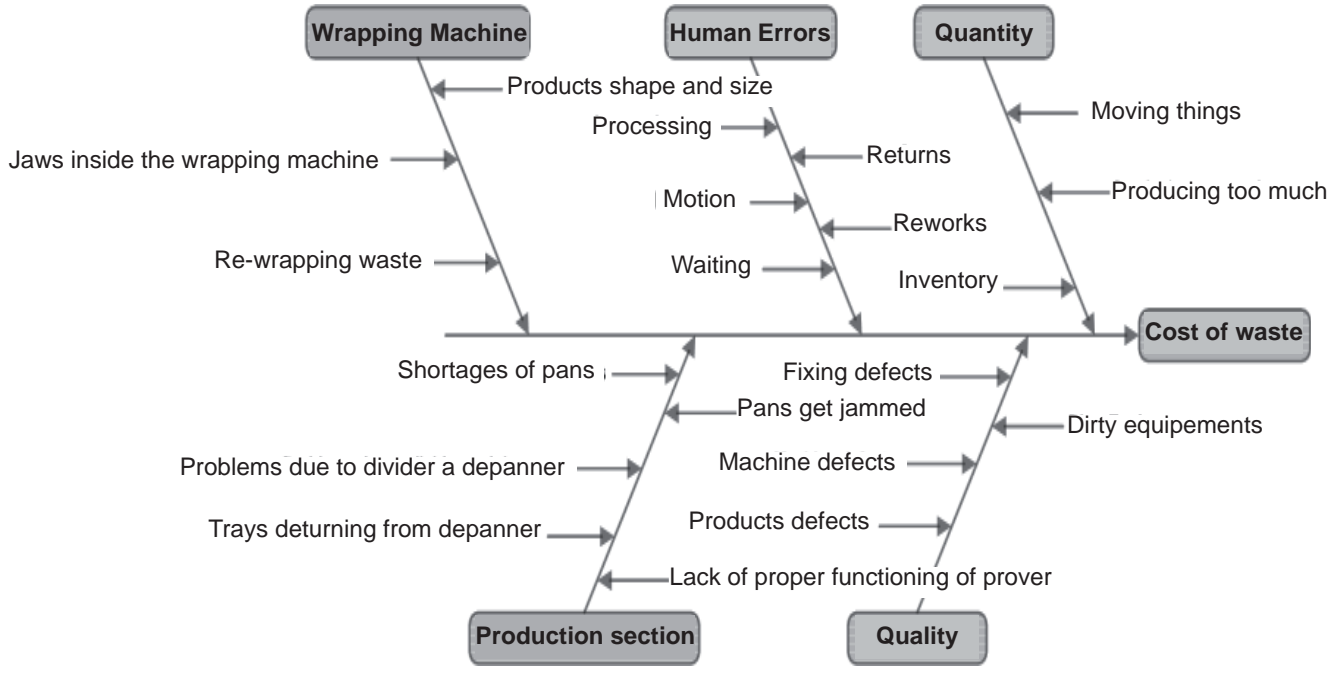

Wastage in $\mathrm{kg}$ in a line over a period is calculated as the sum of individual wastage in $\mathrm{kg}$ in a day for a period of time where $\mathrm{n}=$ number of days. i.e.

The following table summarize the overall calculation for various lines of the data collected from 9 July 2012 to 3 August 2012.

\subsection{Reasons for waste}

Interviews are conducted randomly from three different shifts with the operators, supervisors and managers to find the reasons for waste, and the main reasons for waste inside the wrapping section were:
1) Lack of regular maintenance in the production section.

2) The washing trays and panner get jammed often.

3) There are some defects in the prover machine.

4) Sometimes, the oven also causes some issues.

5) As a result, the products lose quality due to variations in size and shape, dirty bottoms, blistered, over burnt, poor toppings and lack of design on the surface of the products.

6) Another reason is the jaws located inside the wrapping machines of three wrapping lines. Human errors are also one of the reasons to cause waste. 
Figure 7: Reasons for waste
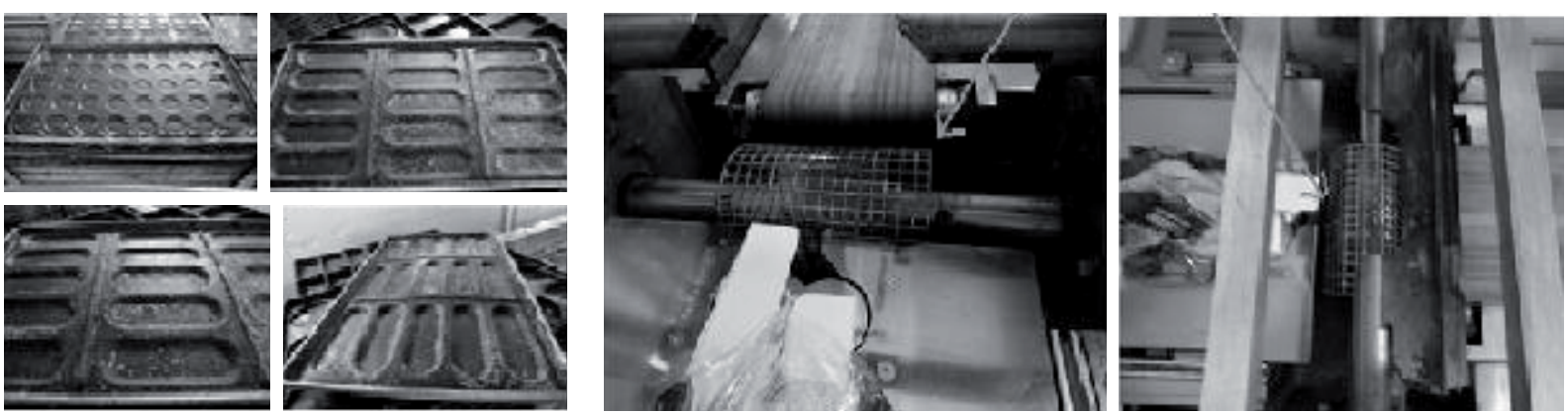

The above figure gives a clear picture about the reasons for waste in the wrapping section.
Figure 8: Good Products
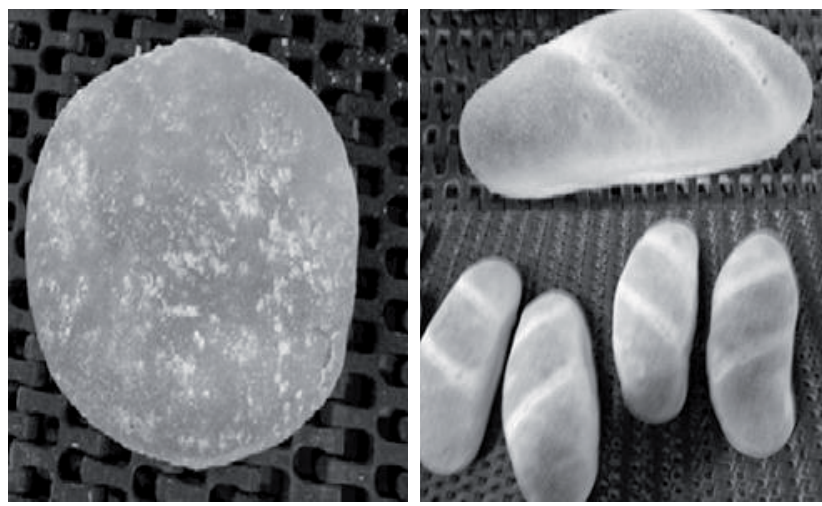

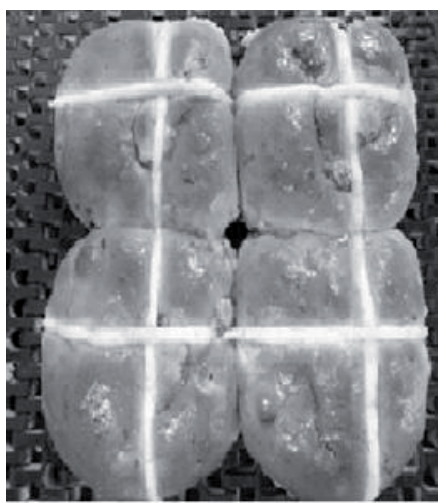

All the above reasons resulted in unnecessary:

1) Waste of time,

2) Re-work and

3) Unwanted Cost to the food industry.

4) It also affected the efficiency of actual quantities wrapped inside the wrapping section.

Figure 9: Reasons for product waste and time waste from the production section

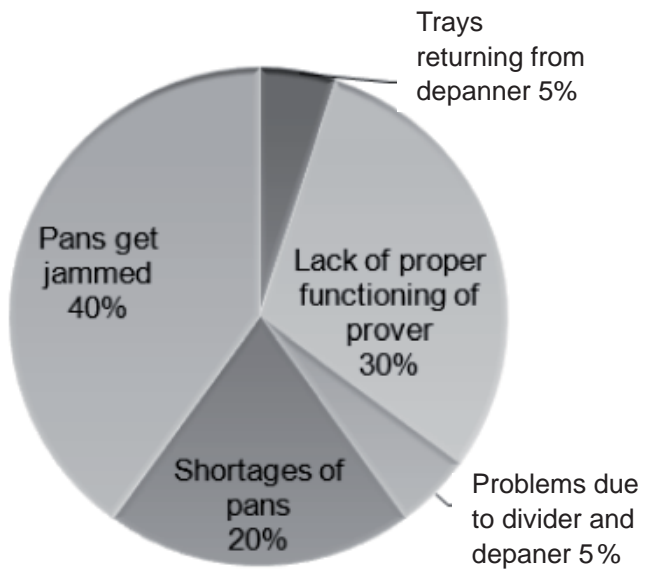

4.3 Total Cost of waste inside the wrapping section:

1) The total cost of waste from Line 1 is $£ 135,580$ pounds per year.

2) The total cost of waste from line 2 and 3 alone for 1 year is $£ 80,084.35$.

3) Therefore, the grand total cost of waste from the wrapping section is $£ 215,664$ pounds per year.

\section{Solutions and Recommendations}

\section{Solution 1: Business Process Improvements}

The process improvements involve small improvements without any major change in layout design and business processes.

\section{Improvement Tools}

To reduce waste and cost associated with it, the following improvement tools are recommended for implementation.
1) $5 S$,
2) Total Quality Management,
3) Autonomous maintenance,
4) Continuous Improvements and
5) Quality Management systems. 
Figure 10: Steps to be followed for re-engineering the current business process at food Industry

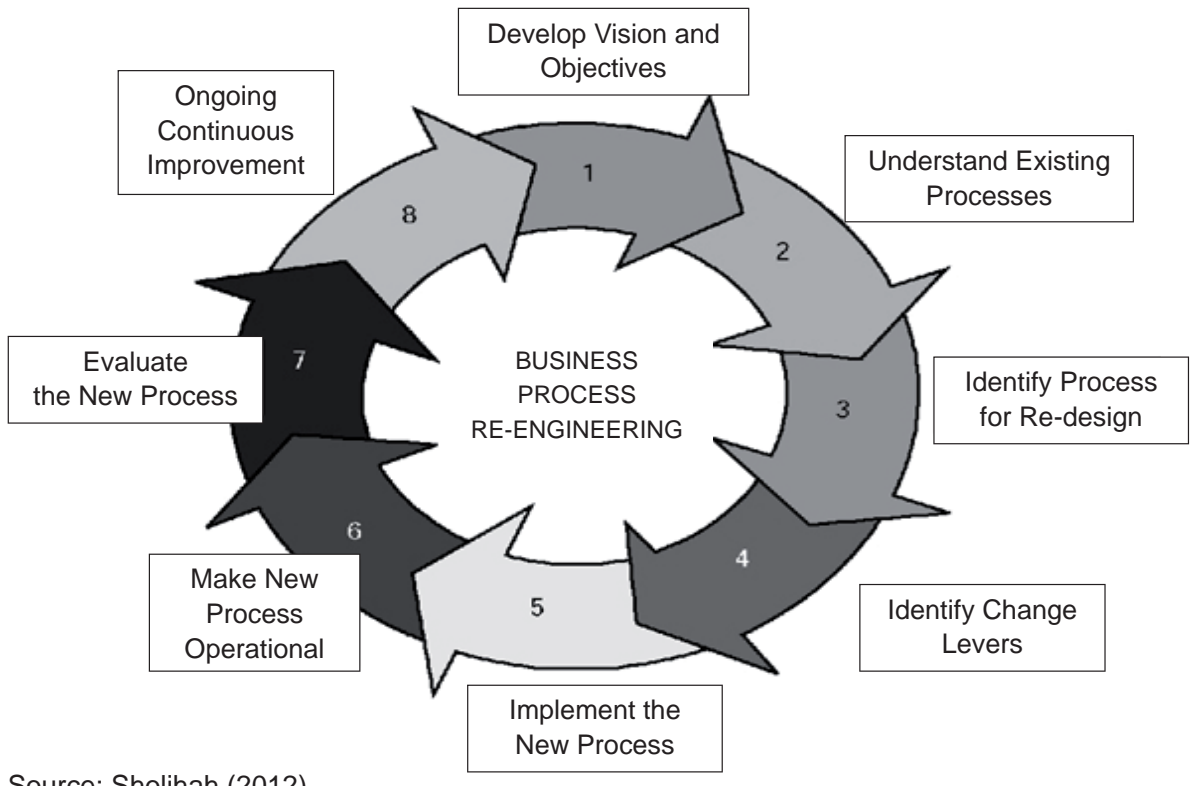

Source: Sholihah (2012)

Figure 11: The proposed business process improvement model for food industry

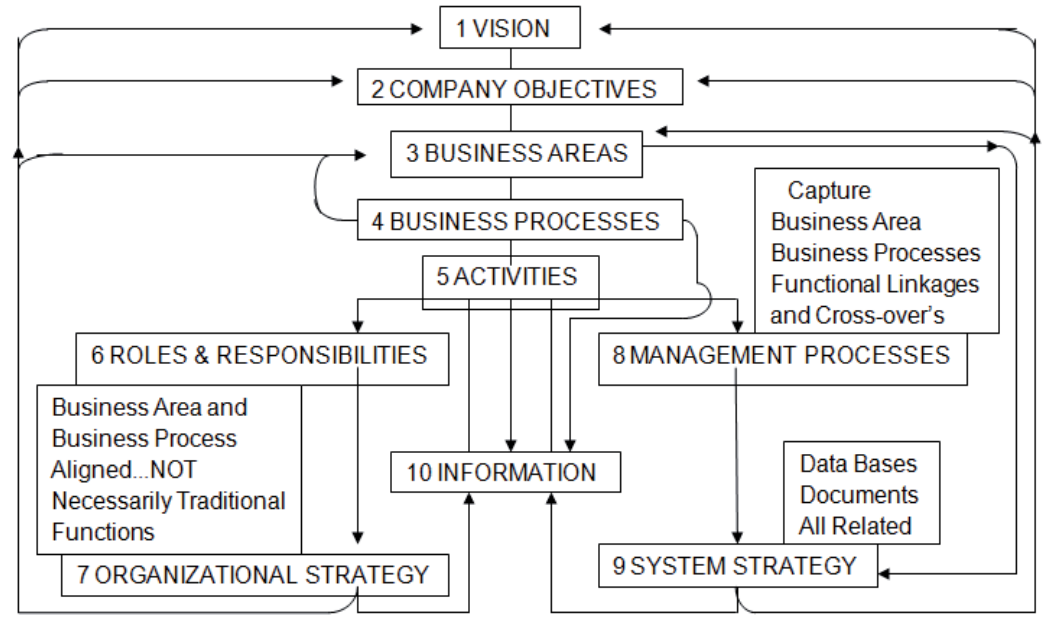

\section{Benefits}

1) The operators can be reduced.

2) It reduces the total lead time.

3) TQM helps to improve quality in the process.

4) The prevention cost, internal and external failure costs, cost of lost opportunities, and cost of exceeding customer requirements can be continuously reduced.

5) Highly improves production activities, customer satisfaction and provide rooms for further improvements.
6) It increases efficiency, organizational development and flexibility.

7) By performing regular maintenance, the machine defects can be highly reduced.

8) It provides shorter changeover times.

9) Improves operator working attendance.

10) Improves value adding activities and ideas per worker. 


\section{Requirements}

1) Requires top management support, teamwork, employee involvement, training, communication, and recognition and rewarded.

2) Once a problem is detected anywhere in the value stream, without solving that problem completely, further proceedings should not be continued.

\section{Solution 2: Business Process Re-Engineering}

The following illustrates the steps to be followed for re-engineering the current business process at the food industry.

According to Sholihah (2012), it is highly recommended to food industry to develop the objectives and vision. It is recommended to understand the current process and identify any process for re-designing. Once the change levers are identified, the new process must be implemented and operated. Then, the new process should be evaluated and continuously monitored and improve the new processes. It should be followed regularly.

The proposed business process improvement model for the food industry:

The following Figure 11 is the proposed model for improving the business process in the food industry. It includes 10 steps for business process improvements as follows: firstly, it is recommended to have a vision and based on that vision, objectives should be set. Next, the organization should focus the business area, business processes, and functional linkages and cross overs. To complete the above steps, it is recommended to assign roles and responsibilities to individuals and develop organizational strategy. At the same time, the management should develop a system strategy. Both the strategies should be effectively conveyed both downstream and upstream.

From the above figure, it can also be shown that a business process is a series of interrelated activities, crossing functional boundaries with inputs and outputs. The above proposed model may help this food industry to improve the business process. Therefore, it is highly recommended to implement the above proposed model and the following procedures.

Without coordination between processes, variances in one process may lead to variances in performance of other processes. So, enhancing organizational coordination is a vital part in process improvement (Garenga, 2011). By developing a process management structure and improvement methods, Gunstones processes may be efficiently defined and effectively managed. Managing processes is concerned with process improvement and this may typically direct to know about how to improve the actual operation of processes (Shafti 2011). For managerial processes, to be concerned with sustaining and enhancing performance in the future, it is highly recommended for this food industry top management to set direction, manage the strategy effectively, build organizational competence, and manage performance and process change (Bititci et al., 2011).

Performance can be enhanced by operational processes. So, it is highly recommended to develop quality in products, increase the order, fulfill the orders with customer satisfaction and it is essential to support the products. It is recommended to combine people and processes through cultural fitness to give output as a result.

To achieve all the above procedures, there is a requirement of process support. So, it is recommended to support

Figure 12: Current state and future state results

\begin{tabular}{|c|c|c|c|}
\hline \multirow[b]{2}{*}{ LINE 1} & \multirow{2}{*}{$\begin{array}{l}\text { CURRENT } \\
\text { STATE }\end{array}$} & \multicolumn{2}{|c|}{ FUTURE STATE } \\
\hline & & $\begin{array}{l}\text { After Business Processes } \\
\text { Improved State }\end{array}$ & $\begin{array}{l}\text { After Business Processes } \\
\text { Resedigned State }\end{array}$ \\
\hline Total Operators & 10 & 6 & 2 \\
\hline Lead Time & $640 \mathrm{sec}$ & $319.2 \mathrm{sec}$ & $306.2 \mathrm{sec}$ \\
\hline Total Cycle Time & $6.3 \mathrm{sec}$ & $4.4 \mathrm{sec}$ & $3 \mathrm{sec}$ \\
\hline Total Lead Time & $646.3 \mathrm{sec}$ & $323.6 \mathrm{sec}$ & $309.2 \mathrm{sec}$ \\
\hline Total Trays & 11980 & 18800 & 27600 \\
\hline \multicolumn{4}{|l|}{ LINE 2 \&3 } \\
\hline Total Operators & 12 & 8 & 4 \\
\hline Lead Time & $643.3 \mathrm{sec}$ & $325 \mathrm{sec}$ & $307 \mathrm{sec}$ \\
\hline Total Cycle Time & $7.8 \mathrm{sec}$ & $5.4 \mathrm{sec}$ & $4.3 \mathrm{sec}$ \\
\hline Total Lead Time & $651.1 \mathrm{sec}$ & $330.4 \mathrm{sec}$ & $311.3 \mathrm{sec}$ \\
\hline Total Trays & 15840 & 16000 & 19256 \\
\hline
\end{tabular}


processes by supporting finance, personnel, technology, facilities, etc. Performance measurement is the key principle to manage processes. So, it is recommended to identify trends, assess stability, and determine whether customer requirements are actually met and drive improvement. So, measurement is central to successful approaches to business process improvements. Excellent metrics may be absolutely fundamental to managing a process and it may drive to examine the tails of distributions of measuring process variation but, not just average values and consistent with the view of statistical process control. By using specific methods like benchmarking and adopting best practices, this may develop compendiums and improve processes. By following the above recommendations, the waste and problems can be eliminated, the business can be improved and as a result, the cost can be saved.

Based on all the above recommendations, it is clear that there is a requirement of top management support and development from bottom; this may effectively improve the business process, staff dedication, and two-way effective communication. As a result, this improves procedures and increases the production.

The final stage of business process change type is re-engineering the entire value chain. It involves the complete change in layout and entire business processes. This may be implemented in future to obtain great benefits from it.

\section{Conclusion}

Comparison of obtained Current State Results and future State Results in Food Industry

The main objectives of this research are to provide optimum resources for the wrapping section and to find the reason for wastages and also to provide a solution to eliminate that waste. The total quantity of wastages from three wrapping lines, the efficiency of the lines' wrapping, and the reasons for wastages are found in this research. The objectives of this research are completed. The findings clearly prove the reasons for wastages. The main reasons behind all this waste are due to the lack of regular maintenance and defective issues with some parts of the production machines, which resulted in the products becoming burnt or blistered, or poor toppings, or they were over topped, had dirty bottoms, were flattened in surface and/or had variations from the normal size and shape. If the machines are maintained and cleaned regularly, the above quality issues in products and machine breakdowns can be avoided. The total costs of all the waste from Line 1, 2 and 3 are calculated. It costs about $£ 215,664.67$ pounds per year. The implementation of lean tools and techniques are the best possible way to eliminate all this waste inside the wrapping section of this food industry.

As mentioned in the literature review, the value stream mapping helped to map the current and future state of the wrapping section and also as discussed in the literature review many manufacturing industries gain benefits of implementing lean manufacturing tools and techniques by reducing their lead times and increasing productivity. The use of lean techniques and value stream mapping in Gunstones Bakery reduced total lead time, and the uptime and productivity was greatly increased.

\subsection{Lessons learned from this Research}

The main lessons learned from this research are lean is a powerful method to eliminate waste and value stream mapping is a powerful tool to map the current and future state of the process. It provided a clear picture of what exactly is happening inside the wrapping section. With the help of this analysis, the non-value adding time was detected. Out of this, a decision was made to overcome the current problem and this helped to provide a solution for future improvements. The total lead time can be reduced; productivity and efficiency can be increased. As a result, the optimum resources can be effectively allocated and used; cost and time can be greatly saved.

\section{References}

Achanga, P., Shehab, E., Roy, R., Nelder, G. (2006). Critical Success factors for lean implementation within SMEs. Journal of Manufacturing Technology Management, 17 (4), 460-471.

Albert, M. (2004). Setup reduction: at the heart of lean manufacturing. Modern Machine Shop, 76 (7), 66-73.

Angra, S., Sehgal, R., Samsudeen Noori, Z. (2008). Cellular Manufacturing - a time based analysis to the layout problem. International Journal of Production Economics, 112 (1), 427-438.

Barla, S. B. (2003). A case study of supplier selection for lean supply by using a mathematical model. Logistics Information Management, 16 (6), 451-459.

Bichino, J. (2000). The Lean Tool Box. 2 ed. Buckingham: Picsie Books.

Bititci, U. S. et al. (2011). Managerial processes: business process that sustain performance.. International Journal of Operations \& Production Management, 3(8), 851-891.

Cequea, A. (2012). What are the Benefits of value Stream mapping?, (available at: http://www.ehow.com/ list_6624878_benefits-value-stream-mapping_html), [accessed 13 August 2012].

Chen, J. C., Li, Y., Shady, B. D. (2010). From value stream mapping toward a lean/sigma continuous improvement process: an industrial case study. International Journal of Production Research, 48 (4), 1069-1086. 
Chowdary, B. V., George, D. (2012). Improvement of manufacturing operations at a pharmaceutical company: A Lean Manufacturing approach. Journal of Manufacturing Technology Management, 23(1), pp. 56-75.

Dekker, H. C. (2003). Value chain analysis in interfirm relationships: a field study. Management Accounting Research, 13 (1), 1-23.

Eatock, J., Dixon, D., Young, T. (2009). An exploratory survey of current practice in the medical device industry. Journal of Manufacturing Technology Management, 20 (2), 218-234.

Evans, B., Simons, D. (2000). Lean delivery road map - how to make it happen. Logistics Focus, 2 (9), 30-39.

Forrester, J. (1958). Industrial dynamics a major breakthrough for decision makers. Harvard Business Review, 36 (4), 37-66

Frøkjær, E., Hertzum. M., Hornbæk, K. (2000). Measuring usability: are effectiveness efficiency, and satisfaction really correlated? Proceedings of the CHI 2000 Conference on Human Factors in Computing Systems, 345-352.

Haque, B. James-Moore, M. (2004). Applying lean thinking to new product introduction. Journal of Engineering Design, 15 (1), 1-31.

Hines, P., Rich, N. (1997). The seven value stream mapping tools. International Journal of Operations \& Production Management, 17 (1), 46-64.

Hines, P., Holweg, M., Rich, N. (2004). Learning to evolve. International Journal of Production and Management, 24 (10), 914-1011.

Hkrita (2009). Value Stream Mapping: Development of a Problem Solving model for the Hong kong Textiles and Clothing Industries, (available at: http:// www.clothingtraining.org.hk/webpage/hkrita-psm/ TrainingMaterials/Value\%20Stream\%20Mapping.pdf), [accessed 13 August 2012].

Hunter, S. L., Black, J. T. (2007). Lean Manufacturing: a Cellular case study. Journal of Manufacturing Systems, 6 (2), 129-144.

Jones, D., Womack, J. (2000). Seeing the Whole. Boston: LEI.

Kao, C. et al. (1995). Productivity improvement:efficiency approach vs effectiveness approach. International Journal of Management Science, 23 (2), 197-204.

Khamis, N. et al. (2009). Development of 5S practice checklist for manufacturing industry. World Congress on Engineering 2009 (Vol. 1), 545.

Khatri, V. (2009). Benchmark 6ix sigma : Is Six Sigma Being Applied In Industry Or Specialization Of My Choice?, (available at: https://benchmarksixsigma.groupsite.com/ post/the-benefits-limitations-of-lean-and-six-sigma), [accessed 13 August 2012].

Lasa, I. S., Castro, R. D., Laburu, C. O. (2009). Extent of the use of Lean concepts proposed for a value stream mapping application. Production Planning and Control, 20 (1), 82-98.

Lian, Y. H., Van Landeghem, H. (2007). Analysing the effects of lean manufacturing using a value stream mapping-based simulation generator. International Journal of Production Research, 45 (13), 3037-3058.

Lummus, R. R., Vokurka, R. J., Rodeghiero, B. (2006). Improving Quality through value stream mapping :a case study of a physician's clinic. Total Quality Management and Business Excellence, 17 (8), 1063-1075.
Matt, D. T. (2008). Template based production system design. Journal of Manufacturing Technology Management, 19 (7), 783-797.

McDonald, T., Van Aken, E. M., Rentes, A. F. (2002). Utilising simulation to enhance value stream mapping:a manufacturing case application. International Journal of Logistics Research and Application:A Leading Journal of Supply Chain Management, 5 (2), 213-232.

Mentzer, J. T., Konrad, B. P. (1991). An efficiency effectiveness approach to logistics performance analysis. Journal of Business Logistics, 12 (1), 33-61.

Monden, Y. (1993). Toyota Production System: An Integerated Approach to Just-in-Time. Norcoss,GA: Industrial Engineering and Management Press.

Nielsen, J., Levy, J. (1994). Measuring usability preference vs. performance. Communications of the ACM, 4, 66-75.

Ohno, T. (1988). Toyota Production System. Cambridge: Productivity Press.

Papadopoulou, T. C., Özbayrak, M. (2005). Leanness: experiences from the jouney to date. Journal of Manufacturing Technology Management, 16 (7), 784-807.

Porter, M. E. (1985). Competitive Advantage. NewYork: The Free Press.

Rother, M., Shook, J. (1999). Learning to See: Value Stream Mapping to Create Value and Eliminate Muda. Brookline: The Lean Enterprise Institute.

Serrano, I., Ochoa, C., Castro, R. (2008). Evaluation of value stream mapping in manufacturing system redesign. International Journal of Production Research, 46 (16), 4409-4430.

Seth, D., Gupta, V. (2005). Application of value stream mapping for lean operations and cycle time reduction: an Indian case study. Production Planning and Control: The Management of Operations, 16 (1), 44-59.

Sholihah, M. (2012). BPR, Prototyping Tool: Business Process Re-engineering, (available at: http://nikmatus-sholihah. mhs.narotama.ac.id/sia-2/tugas-individu-bpr-prototypingcase-tool/), [accessed 5 September 2012].

Simons, D. W., Francis, M., Bourlakis, M., Fearne, A. (2003). Identifying the determinants of value in the UK red meat industry. Journal on Chain and Network Science, 3 (2),109-121.

Slomp, J., Chowdary, B. V., Suresh, N. C. (2005). Design of virtual manufacturing cells: a mathematical programming approach. Robotics and Computer-Integrated Manufacturing, 21 (3), 273-288.

Taj, S. (2008). Lean Manufacturing performance in China: assessment of 65 manufacturing plants. Journal of Manufacturing Technology Management, 19 (2), 217-234.

Tapping, D., Luyster, T., Shuker. T. (2002). Value Stream Management. New York: Productivity Press.

Taylor, D. H. (2006). Strategic considerations in the development of lean agri-food-supply chains: a case study of the UK pork sector. Supply Chain Management: An International Journal, 11 (3), 271-280.

Towill, D. (1996). Industrial dynamics modelling of supply chains. The International Journal of Physical Distribution \& Logistics Management, 25 (2), 23-43. 
Vinodh, S., Arvind, K. R., Somanaathan, M. (2010).

Application of value stream mapping in an Indian Camshaft Manufacturing Organization. Journal of Manufacturing Technology Management, 21 (7), 888-900.

Womack, J., Jones, D. T. (1996). Lean Thinking: Banish Waste and Create Wealth in Your Corporation. New York.: Simon \& Schuster.

Womack, J. P., Jones, D. T., Roos, D. (2007). The Machine That Changed The World. New York: The Free Press.

Yang, T. M., Su, C. T. (2007). Application of Hoshin Kanri for productivity improvement in a semi conductor manufacturing company. Journal of Manufacturing Technology Management, 18 (6), 761-775.

Young, S. M., Shields, M. D., Wolf, G. (1988). Manufacturing controls and performance: an experiment. Accounting Organisations and Society, 13 (6), 607-618.

Yusuf, Y. Y., Adeleye, E. O. (2002). A comparitive study of lean and agile manufacturing with a related survey of current practices in the UK. International Journal of Production Research, 40 (17), 4545-4562.
Zokaei, A. K., Simons, D. W. (2006). Value Chain Analysis in Consumer focus improvement: A case study of the UK red meat imdustry. The International Journal of Logistics Management, 17 (2), 141-162.

\section{Authors}

Chandru Nagarajan Sathiuabama, MSc. Sheffield Hallam University United Kingdom chandruscm88@gmail.com

Pramod Dasan, MBA Faculty of International Relations

University of Economic

Prague Czech Republic pramod.dasan@gmail.com

This article has been created with financial support of the Internal Grant Agency of the University of Economics, Prague, No. of project mF/13/2012. 